\title{
IMPLEMENTASI DISKUSI REFLEKSI KASUS (DRK) MENINGKATKAN KEPATUHAN PERAWAT DALAM MENERAPKAN SOP MANAJEMEN NYERI
}

\author{
Yuni Kurniasih ${ }^{1}$, Ardani $^{2}$, Widiastuti ${ }^{3)}$ \\ ${ }^{1,2,3}$ Universitas Aisyiyah Yogyakarta \\ e-mail : yunikurniasih12@yahoo.com
}

\begin{abstract}
ABSTRAK
Keberhasilan pelayanan kesehatan sangat tergantung pada partisipasi perawat dalam memberikan asuhan keperawatan yang berkualitas. Banyaknya tugas yang hars dilakukan perawat membuat perawat kurang maksimal dalam menjalankan tugasnya sebagai pemberi asuhan keperawatan. Salah satu kegiatan untuk memecahkan masalah yang muncul dalam pelayanan kesehatan salah satunya dengan refleksi kasus yang di Indonesia diperkenalkan melalui kegiatan Diskusi Refleksi Kasus. Penelitian ini bertujuan untuk mengetahui apakah Diskusi Refleksi Kasus (DRK) dapat meningkatkan kepatuhan perawat dalam melaksanakan SPO manajemen nyeri di RS PKU Muhammadiyah Yogyakarta.Jenis penelitian ini adalah Quasi Eksperiment dengan dilakukan pada responden yang berjumlah 35 responden. Analisa data untuk menguji pre dan post menggunakan Uji PairedT-test atauUji T berpasangan. Hasil penelitian ini menunjukan adanya pengaruh yang signifikan kepatuhan penerapan sop manajemen nyeri didapatkan thitung 13.126 dan signifikansi 0,00.
\end{abstract}

Kata kunci: DRK, kepatuhan, manajemen nyeri

\begin{abstract}
The success of health services is highly dependent on the participation of nurses to provide quality nursing care. The number of tasks that must be done by nurses makes nurses less optimal in carrying out their duties as providers of nursing care. One of the activities to solve problems that arise in the health service is one of them by reflecting cases which introduced in Indonesia through the Case Reflection Discussion. This study aims to determine whether the Case Reflection Disscussion (CRD) can increase nurses' compliance in implementing SOP pain management at PKU Muhammadiyah Hospital in Yogyakarta. Data analysis pre and post test used the Paired T-test or Paired T Test. The results of this study indicate that there is a significant effect of compliance with the application of standart operating procedure (SOP) pain management obtained t count 13,126 and a significance of 0.00 .
\end{abstract}

Keyword: Reflective case discussion, compliance, pain management

\section{PENDAHULUAN}

Peningkatan kinerja perawat profesional dan selalu mematuhi SPO dalam memberikan pelayanan pada pasien perlu dilakukan secara terus menerus. Manifestasi yang selalu yang menjadi keluhan pada pasien yang dirawat di rumah sakit adalah nyeri. Nyeri merupakan pengalaman sensorik dan emosional yang diakibatkan adanya kerusakan jaringan yang sedang atau akan terjadi, atau pengalaman sensorik dan emosional yang merasakan seolah-olah terjadi kerusakan jaringan (International Association for the Study of Pain).

Perawat sebagai salah satu tenaga kesehatan di rumah sakit memegang peranan penting dalam mencapai tujuan pembangunan kesehatan (Natasia, 2014). Keberhasilan pelayanan kesehatan sangat tergantung pada partisipasi perawat alam memberikan asuhan keperawatan yang berkualitas (Sawansburg, 2000).

Kegiatan untuk memecahkan masalah yang muncul dalam pelayanan kesehatan salah satunya dengan refleksi kasus yang di Indonesia diperkenalkan melalui kegiatan Diskusi Refleksi Kasus (DRK). Kegiatan keperawatan ini apabila dilakukan secara rutin dan konsisten oleh kelompok keperawatan, maka masing masing akan mondorong perawat untuk lebih memahami hubungan antara standar 
dengan kegiatan yang dilakukan sehari hari (Ulfah, 2014).

Diskusi refleksi kasus (DRK) menurut hasil penelitian Ahmad Iqbal mampu meningkatkan individu dalam membuat perencanaan dan efektif dalam upaya mengembangkan mutu keperawatan (Depkes, 2005). Manfaat lain yang dapat diambil dari pelaksanaan DRK adalah sebagai sarana perawat untuk instropeksi diri terhadap tindakan atau kegiatan kerja yang dilakukan sehingga akan meningkatkan kualitas kerja yang diharapkan (Ratnasari, 2012).

\section{METODE PENELITIAN}

Jenis penelitian ini adalah Quasi Eksperiment. Populasi pada kelompok intervensi sejumlah 96 perawat dan 12 dokter. Tehnik pengambila sampel dalam penelitian ini adalah dengan menggunakan purposive sampling. Penelitian ini dilakukan pada Agustus-September 2019. Sampel yang digunakan adalah 36 perawat di ruang perawatan. Kuesioner yang digunakan alat ukur adalah kuesioner DRK dan SOP manajemen nyeri.

Analisa data untuk menguji pre dan post pada kelompok intervensi dan kelompok kontrol menggunakan Uji PairedT-test atau Uji $\mathrm{T}$ berpasangan. Sebelum dilakukan uji Paired $\mathrm{T}$ Test, dilakukan uji normalitas data menggunakan uji kolmogorof smirnof yang hasilnya sebagai berikut

Tabel 1. Hasil Analisis Uji Normalitas Pre dan Post DRK

\begin{tabular}{|c|c|c|c|}
\hline & & $\begin{array}{l}\text { Pre } \\
\text { DRK }\end{array}$ & $\begin{array}{l}\text { Post } \\
\text { DRK }\end{array}$ \\
\hline \multicolumn{2}{|l|}{$\mathrm{N}$} & 36 & 36 \\
\hline Normal & Mean & 5,3056 & 6,6944 \\
\hline Parameters ${ }^{\mathrm{a}, \mathrm{b}}$ & $\begin{array}{l}\text { Std. } \\
\text { Deviation }\end{array}$ & 1,23796 & 1,14191 \\
\hline Most & Absolute & 213 & ,189 \\
\hline Extreme & Positive & , 149 & , 145 \\
\hline Differences & Negative &,- 213 &,- 189 \\
\hline \multicolumn{2}{|l|}{ Test Statistic } & 213 & , 189 \\
\hline \multicolumn{2}{|c|}{ Asymp. Sig. (2-tailed) } &, $077^{\mathrm{c}}$ &, $153^{\mathrm{c}}$ \\
\hline
\end{tabular}

Tabel 2. Hasil Analisis Uji Normalitas Pre dan Post Penerapan SOP Manajemen Nyeri

\begin{tabular}{|c|c|c|c|}
\hline & & $\begin{array}{c}\text { Pre } \\
\text { Nyeri }\end{array}$ & $\begin{array}{c}\text { Post } \\
\text { Nyeri }\end{array}$ \\
\hline $\mathrm{N}$ & & 36 & 36 \\
\hline Normal & Mean & 55,1111 & 83,5833 \\
\hline Parameters $^{\mathrm{a}, \mathrm{b}}$ & $\begin{array}{l}\text { Std. } \\
\text { Deviation }\end{array}$ & 28,86795 & 36,32502 \\
\hline Most & Absolute & ,223 & 186 \\
\hline Extreme & Positi & 223 & 168 \\
\hline Differences & Negative &,- 166 &,- 186 \\
\hline \multicolumn{2}{|c|}{ Test Statistic } & ,223 & ,186 \\
\hline \multicolumn{2}{|c|}{ Asymp. Sig. (2-tailed) } &, $056^{\mathrm{c}}$ &, $163^{\mathrm{c}}$ \\
\hline
\end{tabular}

Dapat dilihat dari tabel one-sample kolmogorov-smirnov test di atas menunjukkan bahwa data tersebut memiliki nilai Asymp. Sig. (2-tailed) > dari 0,05 sehingga dapat disimpulkan data yang digunakan dalam penelitian data dapat dinyatakan berdistribusi normal.

\section{HASIL DAN PEMBAHASAN}

Analisis nilai deskriptif masing-masing variabel berdasarkan nilai mean, modus, median, standar deviasi dalam tabel 3 . Tabel 3. menggambarkan bahwa pada sebelum dilakukannya pelatihan DRK diperoleh nilai rerata sebelum diberikannya perlakuan yaitu 5.30. Nilai median merupakan nilai tengah yaitu 5.50 dan nilai modus yaitu 6.00. Sedangkan setelah dilakukannya pelatihan DRK diperoleh rerata 6.69, nilai median yang merupakan nilai tengah sebesar 7.00, modus 6.00 dan standar deviasi 1.14.

Kepatuhan penerapan SOP manajemen nyeri sebelum diberikannya intervensi pelatihan DRK didapatkan rerata 55.11, median yang merupakan nilai tengah 52.00, modus 62.00 dan st deviasi sebesar 28.86. Setelah diberikannya intervensi berpa pelatihan DRK maka pelaksanaan SOP manajemen nyeri mendapatkan nilai rerata 83.58 , median 85.00 , modus 40.00 dan st deviasi 36.32 . 
Tabel 3. Hasil Analisis Deskriptif Pre dan Post Test Variabel Diskusi Refleksi Kasus

\begin{tabular}{lcccc}
\hline \multicolumn{1}{c}{ Deskriptif } & Pre DRK & Post test DRK & Pre SOP Nyeri & Post SOP Nyeri \\
\hline Mean & 5,30 & 6,69 & 5,11 & 83,58 \\
Median & 5,50 & 7,00 & 52,00 & 85,00 \\
Mode & 6,00 & 6,00 & 62,00 & 40,00 \\
Std. Deviasi & 1,23 & 1,14 & 28,86 & 36,32 \\
\hline Jumlah & 18,03 & 20,83 & 147,97 & 244,9 \\
\hline
\end{tabular}

Gambaran implementasi DRK dan kepatuhan penerapan SOP manajemen nyeri dapat digambarkan dalam tabel 4.

Berdasarkan tabel 4. Tersebut menunjukan hasil uji paired t-test pada variabel pelaksanaan DRK diperoleh nilai t hitung 7,22 dan signifikansi yaitu 0,00 sehingga $t$ hitung diatas $t$ tabel dan signifikansi dibawah 0,05. Dapat diambil kesimpulan bahwa terdapat perbedaan rerata yang signifikan pelaksanaan DRK pada sebelum dan sesudah perlakuan. Nilai rerata sebelum adanya perlakuan yaitu 5,31 sedangkan setelah adanya perlakuan yaitu 6,69 sehingga dapat diartikan adanya peningkatan pelaksanaan DRK dengan adanya intervensi yang dilakukan.

Kepatuhan penerapan SOP manajemen nyeri sebelum dilakukannya intervensi didapatkan rerata 55,11 dan setelah diberikannya intervensi meningkat menjadi 83,58 . Nilai t hitung 13,126 dan signifikansi 0,00 dapat diambil kesimpulan bahwa terdapat perbedaan rerata yang signifikan kepatuhan pelaksanaan SOP manajemen nyeri sebelum dan sesudah intervensi.

Tabel 4. Implementasi DRK terhadap kepatuhan penerapan SOP manajemen nyeri (n: 36)

\begin{tabular}{|c|c|c|c|c|c|}
\hline Variabel & Kelompok & Rerata & t Hitung & Signifikansi & Keterangan \\
\hline \multirow{2}{*}{ DRK } & Pretest & 5,31 & \multirow[t]{2}{*}{7,22} & \multirow{2}{*}{0,00} & \multirow{2}{*}{ Signifikan } \\
\hline & Posttest & 6,69 & & & \\
\hline \multirow{2}{*}{$\begin{array}{l}\text { Manajemen } \\
\text { Nyeri }\end{array}$} & Pretest & 55,11 & \multirow[t]{2}{*}{13,126} & \multirow{2}{*}{0,000} & \multirow{2}{*}{ Signifikan } \\
\hline & Posttest & 83,58 & & & \\
\hline
\end{tabular}

Kepatuhan penerapan SOP manajemen nyeri di RS PKU Muhammadiyah Yogayakarta menunjukan adanya peningkatan setelah diberikan perlakuan. Hal ini dibuktikan dengan hasil uji t test pada variabel kepatuhan penerapan sop manajemen nyeri diperoleh $\mathrm{t}$ hitung 13,126 dan signifikansi 0,00 sehingga $\mathrm{t}$ hitung diatas $\mathrm{t}$ tabel dan signifikansi dibawah 0,05 .

Adanya pengaruh implementasi DRK terhadap kepatuhan penerapan SOP manajemen nyeri dikarenakan DRK merupakan suatu alat yang dapat meningkatkan akuntabilitas perawat di rumah sakit. Hal ini sejalan dengan penelitian yang dilakukan oleh Pamungkas (2011) bahwa pelaksanaan DRK sangat efektif dan efisien untuk meningkatkan pengetahuan, skill dan akuntabilitas perawat di rumah sakit.
Diskusi refleksi kasusu (DRK) merupakan suatu alat yang efektif dan efisien untuk meningkatkan pelaksanaan SOP manajemen nyeri. Penelitian serupa yang pernah dilakukan oleh Ardani, 2018 yang menjelaskan bahwa ada pengaruh yang bermakna anatara DRK dengan penerapan SOP resiko jatuh pada pasien. Semakin sering dilakukan DRK maka besar harapannya pelaksanaan implementasi SOP resiko jatuh akan semakin baik.

DRK merupakan suatu alat praktek manajemen kesehatan yang digunakan untuk mengembangkan layanan kesehatan yang profesional. Rumah sakit dalam penerapan DRK dalam proses layanan kesehatan khususnya keperawatan merupakan kunci keberhasilan dari konsep ini. Monitoring dan evaluasi yang dapat dilakukan berupa evaluasi proses diskusi 
dan administrasi yang dilakukan (Ujeg, 2017).

Kepatuhan penerapan manajemen nyeri merupakan suatu keharusan bagi perawat yang bertugas diruang perawatan. Pelaksanaan sop manajemen nyeri sebelum dan sesudah intervensi mengalami peningkatan. Manajemen nyeri merupakan suatu penilaian nyeri pada pasien di rumah sakit dari awal pasien masuk sampai pasien dinyatakan sembuh dari penyakitnya. Tindakan pengobatan yang diberikan kepada pasien akan memberikan reaksi tertentu terhadap pasien. Terapi yang diberikan tentunya bertujuan untuk menurunkan intensitas nyeri pasien.

Banyak hal yang berpengaruh terhadap penurunan intensitas nyeri, selain ketepatan pengobatan, caring kepada pasien dan penerimaan dari pasien sendiri akan berpengaruh pada kesembuhan pasien. disamping itu dari segi manajemen layanan difrumah sakit perlu diperhatikan beberapa hal yang mempengaruhi keadaan nyeri pasien seperti salah satunya adalah implementasi diskusi refleksi kasus.

Kebijakan setiap rumah sakit untuk mengembangkan kinerja perawat dan tenaga kesehatan yang bekerja didalamnya. Perawat yang merupakan motor penggerak proses layanan kesehatan dirumah sakit menjadi lini terdepan yang menjamin mutu layanan kesehatan di rumah sakit.

\section{KESIMPULAN}

Berdasarkan dengan tujuan penelitian yang telah ditetapkan, maka peneliti dapat mengambil kesimpulan bahwa terdapat peningkatan yang signifikan implementasi DRK sebelum dan sesudah diberikannya intervensi. Begitu juga dengan kepatuhan penerapan SOP manajemen nyeri yang dilakukan oleh perawat, mengalami peningkatan yang signifikan dari sebelum dan sesudah diverikannya intervensi. Dengan hasil tersebut maka DRK terbukti mampu meningkatkan kepatuhan perawat dalam melaksanakan SOP manajemen nyeri.

\section{SARAN}

Dari ada yang dipaparkan diatas maka Pihak rumah sakit dapat mengembangkan perencanaan peningkatan kualitas SDM melalui pelatihan/ refresh materi DRK dan SOP manajemen nyeri dan berupayan meningkatkan kualitas komitmen organisasi. Institusi pendidikan juga diharapkan memasukan kajian materi DRK sebagai materi wajib yang disampaikan dalam kurikulum pendidikan kesehatan.

\section{REFERENSI}

Ardani. 2018. Diskusi Refleksi Kasus meningkatkan kepatuhan Perawat terhadap Penerapan Standar Prosedur Operasional Pencegahan Resiko Jatuh.

Bullock A, Barnes E, Ryan B, et al. 2014. Casebased discussion supporting learning and practice in optoetry. Ophthalmic Physiol Opt; 34: 614-621.

Curriculum IS. 2013. The Intercollegiate Surgical Curriculum Educating the surgeons of the future.; $1-360$

Departemen Kesehatan RI. 2011. Peraturan Menteri Kesehatan RI No: 1691/MENKES/PER/2011.

Depkes. Pedoman Pelatihan Pengembangan Kinerja Klinik 'Refleksi Diskusi Kasus',

Dawber C. 2013. Reflective practice groups for nurses: A consultation liaison psychiatry nursing initiative: Part 2 - the evaluation. Int J Ment Health Nurs; 22: 241-248.

Dedi Mawardi Pamungkas. 2011Dukungan steakholder terhadappelaksanaan DRK di Rumah Sakit Jogja.

Menkes RI. 2005. KEPMENKES RI NO: 836/MENKES/SK/VI/2005 N. Pengembangan Manajemen Kinerja Perawat dan Bidan.

Natasia N, Loekqijana A, Kurniawati J, et al. 2014. Faktor yang Mempengaruhi Kepatuhan Pelaksanaan SOP Asuhan Keperawatan di ICU-ICCU RSUD Gambiran Kota Kediri Factors Affecting Compliance on Nursing Care SOP Implementation in ICU -ICCU Gambiran Hospital Kediri; 28: 21-25

Notoatmodjo. 2018. Metodologi Penelitian Kesehatan. Jakarta: Rineka Cipta.

Ratnasari M. 2012Faktor-Faktor Manajemen Sumber Daya Manusia Di Puskesmas 
Wilayah Kotamadya Jakarta Barat.

Sugiyono. 2016. Statistika Untuk Penelitian. Bandung: Alfabeta

Swansburg Rc. 2000. Kepemimpinan dan manajemen Keperawatan untuk Perawat Klinis. Jakarta, EGC.

Ulfa M, Sarzuli T. 2016. Pengaruh Faktor Internal dan Eksternal Terhadap Kepatuhan Perawat Dalam Melaksanakan Standar Prosedur Operasional Pemasangan Kateter di Rumah Sakit PKU Muhammadiyah Yogyakarta Unit II; 5: 49-55.

Ujeng. 2017. DRK Dalam Implementasi Pengembangan Manajemen Kinerja: Studi kasus di RSUD Gunun Jati Cirebon. Tesis. 